\title{
Assessment of Groundwater Resources in Jaffna Limestone Aquifer
}

\author{
M. Thushyanthy and C.S. De Silva ${ }^{1}$ \\ Department of Agricultural Engineering \\ University of Jaffna, Jaffna \\ Sri Lanka
}

\begin{abstract}
This study is centered on quantitative estimation of groundwater resources of a selected study area in a limestone aquifer, which is the main resource for agriculture, domestic use and water supply in Jaffna Peninsula. Inflow to the system includes groundwater recharge from precipitation and irrigation and outflow to the system includes lateral groundwater outflow and groundwater extraction. Results showed that the total average annual withdrawal from the study area (0.66 MCM) exceeded the total average annual recharge $(0.57 \mathrm{MCM})$, implying that the system is in deficiency indicating unsustainable water withdrawal. A further recommendation is the establishment of an institution for a groundwater regulatory frame work to optimize the usage of groundwater and to arrest negative groundwater balance.
\end{abstract}

Key words: Limestone aquifer, Groundwater, Recharge, Extraction

\section{INTRODUCTION}

Groundwater is an essential natural resource for sustaining life and environment in the Jaffna Peninsula. Rapid development of agriculture, economy and increase of population due to resettlement cause intensive shortage of water, especially for agricultural purposes. The estimation of annual water balance is critical for water management and development planning. Rajasooriyar et al. (2002) reported that water shortage is a major problem and groundwater often serves as an important and safe source of water for the Jaffna Peninsula in Sri Lanka. The water resources of the basin remain almost constant while the demand for water continues to increase. Moreover, due to uneven distribution of rainfall both in time and the space, water resources are dwindling. This has resulted in increased emphasis on development of groundwater resources. Senarath (1990) pointed out that the development of groundwater resources has not been preceded or accompanied by systematic studies to evaluate the groundwater resource potential. In order to gain an understanding of the systems and their inter relationships within the area, it is necessary to carry out water balance calculations. In carrying out such calculations, it is important to address the quantification of the input and output components.

Recharge from rainfall is the most important among the various components of the water balance equation. Panabokke and Perera (2005) estimated the annual groundwater recharge as 10 million acre feet or about 12,375 million cubic meters (MCM) by taking as $10 \%$ of rainfall as average recharge in Sri Lanka. However, this does not represent the total water stored in the ground since it can only be determined by estimating aquifer volumes and

Faculty of Engineering Technology, The Open University of Sri Lanka, Sri Lanka

Author for correspondence: tmikunthan@yahoo.com 
properties. Quantitative evaluation of groundwater resources of an area is an essential prerequisite for its management because total abstraction from any groundwater resource area does not exceed the long term annual average rate of replenishment. Preferably only $50 \%$ of the annual recharge should be used for abstraction. Dharmasena and Karunainathan (2004) stated that crop losses due to water shortage have been frequently reported due to the fact that farmers do not have adequate knowledge and experience for planning their cultivation according to the availability of groundwater. The groundwater balance studies help in the determination of water deficits and water surpluses during different periods in a year, which is of immense help in solving the problem of agriculture and water resource management. Hence, the objective of this study was focused to assess the groundwater budget and the various inflows and outflows to and from the limestone aquifer.

\section{MATERIALS AND METHODS}

\section{Concept of water balance}

The groundwater balance studies require quantification of all individual inflows to and outflows from a groundwater system and the changes in storage over a given period. According to the statement of Njamnsi and Mbue (2009), the amount of water entering into a control volume minus the amount of water leaving the volume during a defined time period equals the change in the amount of water stored in the volume during that period. The inputs to the monthly groundwater balance are actual recharge from rainfall, and irrigation and boundary inflows. Outputs to the balance are abstraction, and boundary outflows and evapotranspiration (ET) from below the groundwater table by the trees. Without including the ET of tall trees from the groundwater table in the groundwater balance, there will not be an adequate agreement between field results and radial flow model simulation as already proved by De Silva (1995). Abstraction from the aquifer could be indicated by a drop in the groundwater table. When there is recharge there could be a rise in the groundwater table. If there is a drop in groundwater level due to abstraction, the actual recharge plus change in groundwater storage plus boundary inflows should be equal to the abstraction plus ET from the tall trees and boundary outflows. When there is a groundwater level rise due to recharge, the difference between the actual recharge and the change in storage plus boundary inflow should be equal to the abstraction plus boundary outflows plus ET from tall trees. Therefore, the general relationship of the monthly groundwater balance components are as flows.

$$
\mathrm{RCH}+\mathrm{IF} \pm \Delta \mathrm{GWS}-\mathrm{ABS}-\mathrm{OF}-\mathrm{Qevp}=0
$$

In which

$$
\begin{array}{ll}
\text { RCH } & - \text { Potential Recharge } \\
\text { IF } & - \text { Inflow to the boundary } \\
\text { OF } & \text { - Outflow from the boundary } \\
\text { ABS } & - \text { Abstraction } \\
\text { Qevp } & \text { - Evapotranspiration from tall trees } \\
\Delta \text { GWS } & \text { - Change in groundwater storage } \\
& \text { All the above values are expressed in } \mathrm{m}^{3} / \mathrm{d} .
\end{array}
$$

Based on this concept, groundwater balance components relevant to the study area were identified and estimated. 


\section{Selection of the study area}

The study area associated with wells with surface contours is shown in Figure. 1. One suitable catchment boundary was identified to continue water balance studies. The East, South and West boundaries of the selected area were taken as no flow boundaries and only the North boundary was taken as the flow boundary. The flow boundary was selected based on the water flow direction in the catchments using the contour map. The area associated within the selected boundaries was $1.26 \mathrm{~km}^{2}$ and contains six wells. All the wells were closely monitored for all the activities such as daily abstraction, daily water level before irrigation and cultivation practices.

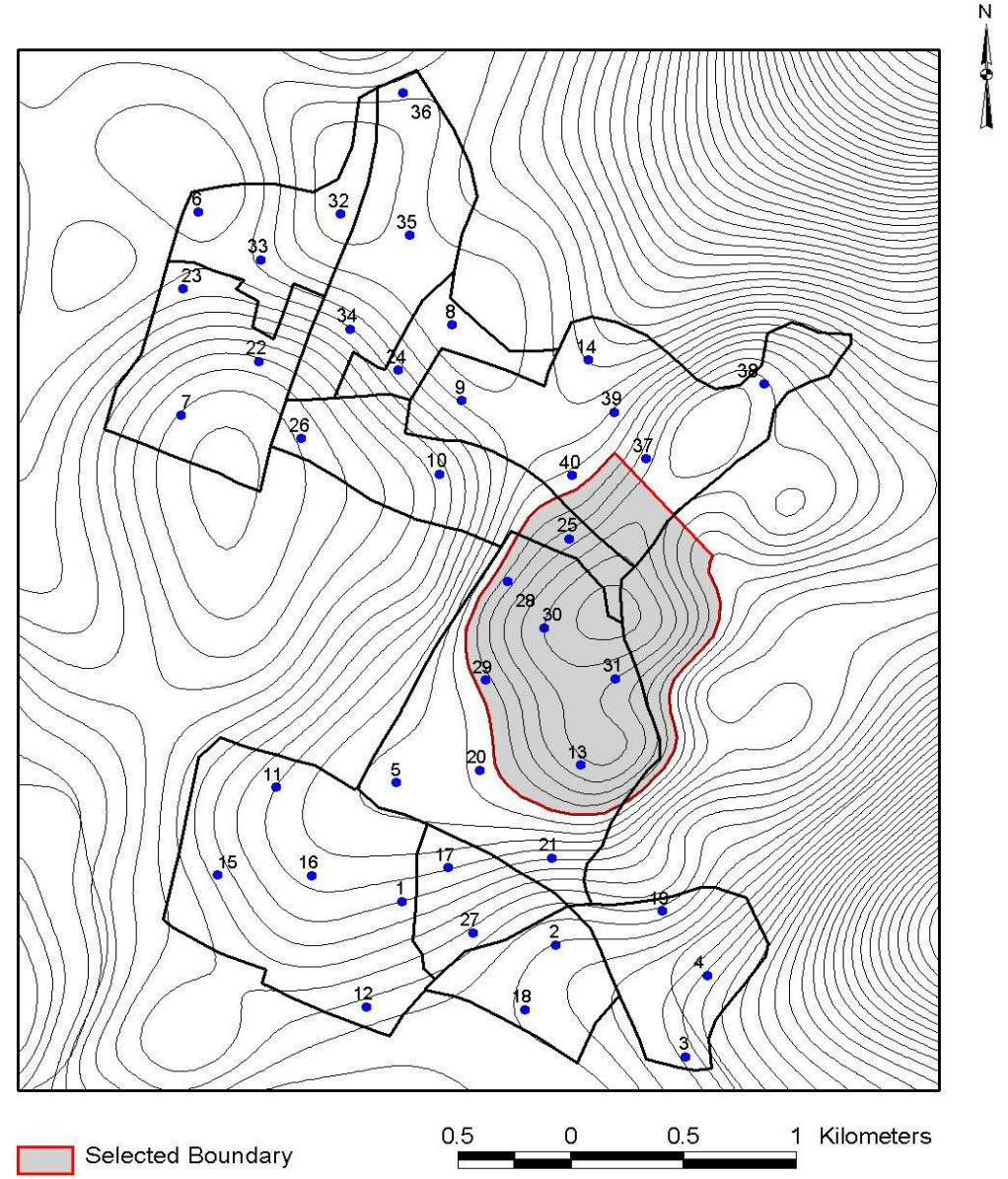

Fig. 1. The study area with selected wells and contours

\section{Estimation of components for water balance}

\section{Changes in groundwater storage}

The differences between water table positions were observed from daily groundwater table fluctuation from the selected wells. Specific yield was estimated using a single well pumping test analysis (Ragunathan, 1987). The change in the groundwater storage ( $\Delta \mathrm{GWS}$ ) was 
estimated by average change in the water table multiplied by area and multiplied by specific yield.

\section{Estimation of recharge}

The recharge was estimated from all six well locations separately by using modified soil moisture balance (MSMB) method (Rushton, 2003; Rushton et al., 2006; De Silva \& Rushton, 2007) by substituting all other individual components separately. The different extents of land use were observed. An average crop factor for each land use was allocated. The $\mathrm{ET}_{\text {crop }}$ for each category of land use were estimated by applying appropriate crop factors in relation to the potential ET. The MSMB method provides periodical estimates of direct recharge based on changes in the soil moisture content. According to the method, the direct recharge occurs when the soil moisture content reaches the field capacity. At the field capacity, any additional net influx of water will not be stored within the soil, but will drain to the aquifer below. The depth of recharge from six locations was averaged and changed to recharge volume by multiplying the respective area.

\section{Subsurface outflow}

Daily groundwater levels were converted into meters below mean sea level to get the hydraulic gradient. Darcy's law was used to calculate the groundwater flow with the estimated hydraulic conductivity of $13.3 \mathrm{~m} / \mathrm{d}$ (Punthakey \& Gamage, 2007), groundwater flow gradient and cross sectional flow area in the field. The hydraulic gradients were derived by averaging the monthly groundwater levels between the well numbers 25 and 37 (Fig. 1) and the distance between these two wells $(640 \mathrm{~m})$. The cross section area is obtained from the length $(650 \mathrm{~m})$ and depth $(30 \mathrm{~m})$ of the limestone. According to the investigation carried out by the Water Resources Board, Jaffna in 1982, the total depth of limestone in two location at the study areas were $31.1 \mathrm{~m}$ and $32 \mathrm{~m}$, respectively (Punthakey \& Gamage, 2007). The whole groundwater regime is assumed to be at steady state condition in a closed system. Based on the above assumptions and parameters, the average groundwater flow was calculated on a monthly basis and separate quantities were then calculated in $\mathrm{m}^{3} / \mathrm{d}$ for the actual area.

\section{Draft from groundwater}

Six wells were monitored continuously for estimating the groundwater abstraction. The monthly groundwater abstraction was calculated using pumping rate, daily pumping hours and number of pumping days in a month for each well. The monthly average abstraction of agricultural well, domestic and home garden well, public well and domestic wells were estimated. Further, numbers of wells from each group were taken by the observation of the study area. The total abstraction was then estimated by multiplying the number of wells by the average abstraction rate of each type of well. Finally, the total monthly abstraction was estimated from the addition of extraction from all the wells.

\section{Evaporation from the tall trees}

De Silva (1995) carried out a water balance study in the Kurunagala which consists of complex land use patterns with the remnant forest trees and other big trees. The tree evaporation was included as a negative relationship to the water table depth up to $4 \mathrm{~m}$ depth and confirmed that evaporation from tall trees is an inseparable component of the ecosystem, and may cause a serious error in the groundwater balance of the aquifer system if it is not 
included. But, in the study area the water tables were below the $4 \mathrm{~m}$ and the evaporation from the tall trees was taken as zero. Umar et al. (2008) evaluated the component of ET from the groundwater table as evaporation flux expressed as an inverse power function of the depth to water table below the soil surface while doing the groundwater balance studies in Western Uttar Pradesh watershed.

\section{RESULTS AND DISCUSSION}

Table 1 shows the monthly groundwater balance without the component of evaporation from groundwater table by the tall trees for 2007 April to 2008 March. The specific yield value of 0.27 was estimated from pumping test and taken for groundwater balance studies in Chunnakam limestone aquifer.

\section{Monthly groundwater balance}

The rainfall recharge, out flow, abstraction and storage change with deviation is shown in Table 1 for each month on average daily basis from April 2007 to March 2008. The abstraction from public wells was very low (less than $1 \mathrm{~m}^{3} / \mathrm{d}$ ) since the method of extraction is manual. The average extraction from domestic wells varies within the range of $1 \mathrm{~m}^{3} / \mathrm{d}$ to $1.25 \mathrm{~m}^{3} / \mathrm{d}$. Also domestic wells with garden usage vary in the range of $2-3 \mathrm{~m}^{3} / \mathrm{d}$. The average abstraction for agricultural activities from farm wells were varied from 13 to $19 \mathrm{~m}^{3} / \mathrm{d}$. During July and August, some of the agricultural well abstraction was around $3 \mathrm{~m}^{3} / \mathrm{d}$ since cultivation was limited, but during the same period domestic wells with garden usage was greater than $3 \mathrm{~m}^{3} / \mathrm{d}$. The variation of water usage was mainly depending on crop type, season, number of rainy days and the total rainfall. Average abstraction among different usage were $71.2 \%, 16.9 \%, 8.5 \%$ and $3.4 \%$ for agriculture, domestic with home garden, domestic and public wells, respectively. The highest water usage was observed in agriculture. According to the study of Thirruchelam (1994), the estimated agriculture water use for Valigamam region at $40 \%$ irrigation efficiency was $106.86 \mathrm{MCM}$. This is about $78 \%$ of the total recharge leaving the balance for non-agricultural uses.

Table 1. Monthly groundwater balance ( $\left.\mathrm{m}^{3} / \mathrm{day}\right)$ of the study area from April 2007 to March 2008

\begin{tabular}{lccccc}
\hline Period & Recharge & Outflow & Abstraction & Storage change & Deviation \\
\hline April & 0 & -190 & -1799 & +2062 & +73 \\
May & 0 & -182 & -1927 & +2176 & +67 \\
June & 0 & -178 & -2048 & +2261 & +35 \\
July & 0 & -183 & -1995 & +2202 & +24 \\
August & 0 & -182 & -1712 & +1978 & +84 \\
September & 879 & -178 & -1792 & +1131 & +40 \\
October & 5174 & -182 & -1280 & -3663 & +49 \\
November & 3559 & -243 & -1164 & -2114 & +38 \\
December & 6657 & -174 & -1012 & -5393 & +78 \\
January & 518 & -174 & -2213 & +1964 & +95 \\
February & 0 & -162 & -1846 & +2062 & +54 \\
March & 2220 & -178 & -1058 & -904 & +80 \\
\hline
\end{tabular}


The highest groundwater outflow occurs in the month of November, 2007 and the outflow in almost all other months during the rest of the study period were not significantly varied. The monthly water balance showed that the potential recharge was mainly during the Maha season from October to December. The Yala season recharge was approximately $14 \%$ of the Maha season. An average groundwater table drop of $85.19 \mathrm{~cm}$ was observed from April to September in 2007 mainly owing to abstraction from the wells. A groundwater table rise was observed from October to December when there was low abstraction and mainly due to recharge to the aquifer during the Maha season. During the study period in the selected area, water levels were below $4 \mathrm{~m}$. Thus, there is no effect of evaporation from tall trees.

The amount of potential recharge predicted by the MSMB method was in par with the water balance during the entire study period except for November. The potential recharge derived from the MSMB method may underestimate the actual amount of water that could be stored by the aquifer, leaving excess water for example during the month of November. There was an unbalanced situation among inflow to outflow in November during the Cyclone "Nisha". Hence, modification in potential recharge is important while doing the groundwater balance during this type of torrential rainfall and flood periods.

In balancing the inputs to outputs in Table 1, there were some inputs which are difficult to explain for some unknown reasons. Theoretically, the groundwater equation must balance, but it is rarely happens in practice as there may be some uncertainties in the estimation of the various parameters. The amount of uncertainty can be shown as a residual term including errors in the estimation of the individual components and all minor and insignificant components neglected in the groundwater balance equation (Chen et al., 2005). For example, the aquifer system was considered as unconfined aquifer and does not account for the interflow between the layers in aquifer and includes the standing water in the surface depressions as these were prominent in the study area. Groundwater balance for the water year from April 2008 to March 2009 was failed due to abnormal situation of cyclone. Hence, groundwater balance of the water year from April 2007 to March 2008 was taken for annual accounting.

\section{Annual groundwater balance}

Table 2 summarizes a crude annual groundwater balance. The main reason for the minus groundwater balance is the over exploitation. Results of the water balance study clearly shows the falling trends in groundwater storage, thereby demonstrating over exploitation of the groundwater aquifer.

Table 2. Summary of water balance calculations (April 2007 - March 2008)

\begin{tabular}{llr}
\hline Components & Estimated values $\left(\mathbf{m}^{\mathbf{3}} / \mathbf{a n n u a l}\right)$ \\
\hline Recharge & $+569,624$ \\
Total withdrawals & & \\
\multicolumn{1}{c}{ Abstraction } & & $-595,350$ \\
Out flow & & $-66,285$ \\
Balance & $\mathbf{+ 5 6 9 , 6 2 4}$ & $\mathbf{- 6 6 1 , 6 3 5}$ \\
Change in storage & \multicolumn{2}{c}{$\mathbf{9 2 , 0 1 1}$} \\
\hline
\end{tabular}

Based on a groundwater balance results (Table 2), the average annual groundwater recharge was $569,624 \mathrm{~m}^{3}(0.57 \mathrm{MCM})$ from April 2007 to March 2008 and the average annual 
groundwater withdrawal was $661,635 \mathrm{~m}^{3}(0.66 \mathrm{MCM})$ resulting a negative water balance of $92,011 \mathrm{~m}^{3}(0.09 \mathrm{MCM})$. Rainfall during the study period was $1471 \mathrm{~mm}$ which was higher than the ten years average annual rainfall of $1284 \mathrm{~mm} /$ year. As such, the estimated available water is expected to be higher than for average years. Even then there was a deficiency in water balance.

This raises the question about the sustainability of groundwater usage in the study area. The safe yield of groundwater aquifers on a sustainable basis and generally it is only the $50 \%$ of the annual replenishment or recharge. However, in the study area the abstraction has exceeded even $100 \%$ of the annual recharge. Continuing overdraft exceeding the safe yield may subsequently lead to progressive decline in groundwater table in the study area. This result had been supported earlier by Rajasooriyar et al. (2002) where the groundwater level patterns for the period from 1979 to 1997 show differences in water level elevations by increasing the area of negative level elevations. Authors mentioned that excessive extraction of groundwater from wells, particularly from agricultural wells using highly efficient electrical pumps for prolonged periods, was the main course of the reduction in groundwater elevations. The results of both studies clearly revealed that over exploitation during dry months. The main problem was that the farmers have a sense of ownership of groundwater which occurs under their land. Increase in pumping is due to farmers' personal initiative, but recharge augmentation is traditionally treated as a private responsibility.

\section{Suggestions for groundwater regulatory framework}

(i) Develop farm level organizations

Formation of an institution of a groundwater regulatory framework is recommended to build up and implement policies to achieve successful sustainable groundwater management. High water usage was observed in the agricultural sector. Hence, considering the overdraft, proposed action will be based on conservation practices, implementation to reduce water demand and increase water use efficiency. Water conservation activities are successful in increasing the water use efficiency. Selection of proper crops and irrigation practices are tools in demand management. Poor cooperation was observed among the farmers at field level. Developing farmer organizations will help to coordinate between farming community to plan the abstraction rate in different time periods which reduces the up corning of seawater into the fresh water and is the key to a successful groundwater development scheme.

(ii) Policy to renovate all existing surface tanks

The results of the groundwater balance study can be used in the decision making process of abstraction of groundwater for agricultural purposes especially during dry seasons. Efforts should be initiated to tap the surface runoff water by creating and renovating storage at suitable sites to increase the recharge. Conjunctive use of the surface water from the main land for domestic and groundwater for agricultural activity with water conservation practices will help to arrest the progressive decline in groundwater aquifer.

(iii) Restriction to use high power pumps for abstraction

Restrictions for the construction of new tube wells and usage of high powered mechanical water pumps, limit the duration of continuous extraction of water and allow for the recovery of well and constructing rainwater reservoirs in public places are some of recommendations that will help in positive storage in the aquifer. 
(iv) Regular monitoring of groundwater levels

Regular monitoring of groundwater levels is essential for proper resource management. Therefore, a government agency should be introduced to monitor daily groundwater levels in the wells. National Water Supply and Drainage Board, local schools and Department of Agrarian development could be used for the purpose.

(v) Awareness programme for farmers

Extension service through Department of Agriculture could be introduced to educate farmers on the consequences of over abstraction on groundwater quantity and quality aspects.

\section{CONCLUSIONS}

The potential recharge of the studied limestone aquifer in Jaffna Peninsula in the dry season was approximately $14 \%$ of the wet season. The amount of potential recharge predicted by the MSMB method tallied with the monthly water balance except during torrential rainfall and flood period. The groundwater balance showed that the boundary outflows were predominant only during the wet season. The annual recharge of groundwater was $0.57 \mathrm{MCM}$ from April 2007 to March 2008 and annual average withdrawal was 0.66 MCM resulting in a deficiency of $0.09 \mathrm{MCM}$ in the water balance leading to water storage or depletion of water and overexploitation of the groundwater aquifer. Therefore, it is imperative to introduce a groundwater regulatory framework to control the deterioration of available groundwater resources in Jaffna peninsula.

\section{REFERENCES}

Chen, J.F., Lee, C.H., Yeh, T.C.J. and Yu, J.L. (2005). A water budget model for the YunLin plain, Taiwan. Water Res. Mgt. 19, 483-504.

De Silva, C.S. and Rushton, K.R. (2007). Groundwater recharge estimating using improved soil moisture balance methodology for a tropical climate with distinct dry season. Hydrol. Sci. J. 52(5), 1051-1067.

De Silva, C.S. (1995). The use of agro wells for supplementary irrigation from hard rock aquifers in Sri Lanka. Thesis submitted in fulfillment of the requirement for the degree of Doctor of Philosophy, Silsoe College, Cranfield University, UK.

Dharmasena, P.B. and Karunainathan, T. (2004). Characteristics of regolith aquifers and their save exploitation through agro-wells. Annals of the Sri Lanka Dept. of Agric. 6, 79-87.

Njamnsi, Y.N. and Mbue, I.N. (2009). Estimation for groundwater balance based on recharge and discharge: A tool for sustainable groundwater management. J. of Am. Sci. 5(2), 83-90.

Panabokke, C.R. and Perera, A.P.G.R.L. (2005). Groundwater resources of Sri Lanka. Water Resources Board, Colombo, Sri Lanka.

Punthakey, J.F. and Gamage, P.D.N. (2006). Coupled flow and salinity transport modelling and assessment of groundwater availability in the Jaffna Peninsula, Sri Lanka. $32^{\text {nd }}$ WEDC International Conference 2006, Colombo, Sri Lanka. 
Ragunathan, H.M. (1987). Groundwater. Willy eastern limited, New Delki, India. pp 240242 .

Rajasooriyar, L., Mathavan, V., Dharmagunawardhane, H.A. and Nandakumar, V. (2002). Groundwater quality in the Valigamam region of the Jaffna Peninsula, Sri Lanka. In: Sustainable groundwater management. Hiscock, K.M., Rivett, M.O., Davison, R.M. (Eds). Geological Society, London. 193, 181-197.

Rushton, K.R. (2003). Groundwater Hydrology, Conceptual and Computational models. John Wiley and Sons Ltd, Chichester, UK.

Rushton, K.R., Eilers, V.H.M. and Carter, R.C. (2006). Improved soil moisture balance methodology for recharge estimation. J. of Hydrol. 318, 379-399.

Senarath, D.C.H. (1990). Two case studies in estimation of groundwater recharge. Groundwater monitoring and management. In: Proceedings of the Dresden symposium, March, 1987. IAHS publication, no. 173, 1990.

Thirruchelvam, S. (1994). An economic analysis of groundwater use in the Jaffna district for agriculture. Thesis submitted in fulfillment of the requirement for the degree of Doctor of Philosophy. Postgraduate Institute of Agriculture, University of Peradaniya, Sri Lanka.

Umar, R., Khan, M.M.A., Ahmed, I. and Ahmed, S. (2008). Implications of Kali-Hindon inter-stream aquifer water balance for groundwater western Uttar Pradesh. J. of Earth Sys. Sci. 117(1), 69-78. 